\title{
Comparative study of antibacterial activity of two different earthworm species, Perionyx excavatus and Pheretima posthuma against pathogenic bacteria
}

\author{
Nitish Bansal, R. K. Gupta*, Dharambir Singh and Shashank \\ Department of Zoology, CCS Haryana Agricultural University, Hisar-125004 (Haryana) \\ *Corresponding author: Email id: rkgupta211066@gmail.com \\ Received: January 1, 2015; Revised received: July 6, 2015; Accepted: August 24, 2015
}

\begin{abstract}
Disease outbreaks are being increasingly recognized as a significant constraint on aquaculture production and trade affecting the economic development of the sector in many countries. Extracting and using biologically active compounds from earthworms has traditionally been practiced by indigenous people throughout the world. The aim of the present study was to shown antimicrobial activity through earthworm extract against fish bacterial pathogens. In total, 8 bacterial strains i.e. 6 gram negative viz. Aeromonas hydrophila, Pseudomonas aeruginosa, $P$. fluorescens, E.coli, Enterobacter aerogens and Shigella sp. and 2 gram positive viz. Staphylococcus aureus and Micrococcus luteus were identified. The extract of earthworm Perionyx excavatus, Pheretima posthuma were prepared and antimicrobial activity of the extract was determined by antimicrobial well diffusion assay. After 24 hrs of incubation period, it was observed that earthworm extract showed antibacterial activity against isolated bacterial strains. Among earthworm extract of two different species, the maximum zone of inhibition was shown against $A$. hydrophila by Perionyx excavatus $(18.33 \pm 0.66 \mathrm{~mm})$ and $P$. posthuma $(16.66 \pm 0.33)$. $P$. excavatus showed antibacterial activity against all pathogenic bacteria except Shigella spp. However on the other hand, P.posthuma showed antibacterial activity against $A$. hydrophila, $P$. fluorescens, E.coli, and $S$. aureus. The study has proved that earthworm extract can be effectively used for suppression of bacterial infection in fishes and that it can used as potential antimicrobial drug against commercial antibiotic resistance bacteria.
\end{abstract}

Keywords: Bacteria, Common carp, Perionyx excavatus, Pheretima posthuma, Zone of inhibition

\section{INTRODUCTION}

Fishes are the main source of animal protein for about one billion people worldwide. Fish products provide $15 \%$ or more of the protein consumed by nearly 3 billion people and support the livelihoods of 520 million people (FAO, 2009). The fisheries sector contributes significantly to the Indian agricultural economy. According to report 2011-12 of department of animal husbandary and dairying, ( Ministry of Agriculture, Govt. of India) that India's total fish production in 2010-2011 was 8.44 million tones. The share of fisheries in the national GDP is 1.5 per cent and in agricultural GDP is 5.0 per cent. Sustained and enhanced productivity are the major goals of aquaculture. Aquaculture thus has become an important economic activity in many countries and plays an important role in the socio- economic development of the country (http://nfdb.gov.in/html/aboutus.htm). Diseases and pollution play an important role in aquaculture. Bacterial disease outbreaks impose a significant constraint on the production of fish and shellfish (Bachère et al., 1995; Verschuere et al., 2000; Gomez et al., 2007). Bacterial pathogens have been reported to cause heavy mortality in both cultured and wild fish species in different parts of the world (Joseph and Clerk, 2002;
Bader et al., 2003;). The facultative bacterial pathogens prove a potential threat, when fish are under environmental and physiological stress (Kirjusina et al. 2007). Furthermore, there is a growing concern about the use and particularly, the abuse of antimicrobial drugs not only in human medicine and agriculture but also in aquaculture. The use of anti microbial drugs in agriculture and aquaculture has led to the emergence of antibiotic resistant bacteria (Schwarz et al., 2001; Akinbowale et al., 2006).

Extracting and using biologically active compounds from earthworms has traditionally been practiced by indigenous people throughout the world, more particularly in Asia, including India, Myanmar, China, Korea and Vietnam (Ranganathan, 2006). Earthworms have been known for many centuries as a therapeutic drug source for various diseases in China and other parts of the Far East (Ismail, 2005). In Korea, earthworms are believed to promote general health and prevent a wide variety of diseases (El-Kamali, 2000). Studies on earthworm have shown its antipyretic, antispasmodic, detoxic, diuretic, antihypertensive, antiallergic, anticoagulative, antiasthmatic, spermatocidal, antioxidative, antimicrobial, anticancer, antiulceral and anti-inflammatory activities (Hrzenjak et al., 1998; John and Packialakshmi, 2007; Shobha and Kale, 
2007; Wang et al., 2007; Balamurugan et al.,2009; Ansari and Sitaram, 2010; Cooper and Balamurugan, 2010 ).

Earthworms are soil macro invertebrate oligochaete animals that play an important role in the sustainability of soil fertility and productivity. Many tribes and people in remote villages in India are known to use earthworms to treat various kinds of ailments. Recently earthworm protein and its coelomic fluid were reported to exhibit cytolytic, agglutinating, proteolytic, haemolytic, mitogenic, tumorstatic and antibacterial activities (Edwards and Bohlen, 1996; Popovi et al., 2001; Cooper, 2005). Further extracts from the earthworm in different solvents were studied in carrageenin-induced oedema and cotton pellet granuloma in rats and showed anti-inflammatory property (Yegnanarayan et al., 1988). Very recently Prakash et al. (2007) and Balamurugan et al. (2007) have reported that the presence of anti-ulceral and anti-oxidative properties of earthworm paste of Lampito mauritii. Traditional medicine practitioners in Tamilnadu (India) use the earthworm, in its decoction form, to treat fever, stomach pain, neck pain, neural disorders and digestive disorders (Murugan siddha practitioner, Oral communication). However there are no scientific data available to prove the claim of the traditional medicine practitioners about the medicinal effectiveness of earthworms. A significant number of studies have been carried out by researchers across the globe for assessing and evaluating the antibacterial and anti-inflammatory activity of earthworm powder/paste/extract. However, almost negligible attempts have been made to study this extra-ordinary property of earthworms in fish disease management.Therefore the present study was undertaken to analyze some of the ethnomedical uses of earthworm, as antibacterial activity using different indigenous earthworm species against pathogenic bacteria isolated from Cyprinus carpio.

\section{MATERIALS AND METHODS}

The study was carried out at Fish Biotechnology Laboratory and Aquarium Room, Department of Zoology, Chaudhary Charan Singh Haryana Agricultural University, Hisar. The following materials and methods were used during the research work.

Isolation, culture and identification of bacterial strains from fish: Healthy and infected fish (Cyprinus carpio) were collected from fish farms/ponds in Hisar (Haryana) and brought to the Fish Biotechnology Laboratory of the department. The external symptoms of the infected fish were recorded. The specimens were kept under laboratory conditions for isolation and the identification of bacterial strains.

Firstly diseased fish, common carp procured and tissue and organs were aseptically collected from diseased fish and by using gram staining method identification of the bacterial pathogens were done. The tissues and organs (skin lesions, gills and intestine) were dissected out and homogenized by the homogenizer in the glass tube. The supernatant was spread over the nutrient agar (NA) medium under aseptic conditions. The culture plates of bacteria were incubated in B.O.D at $30 \pm 2{ }^{\circ} \mathrm{C}$ for 18-24 hours. Growth on NA plate was observed after 18-24 hours. Pure colonies of bacteria were obtained by further sub-culturing single colonies on NA plates. Isolated pure culture bacteria were subjected to a number of important biochemical tests (primary and secondary tests for identification) described by Krieg and Holt (1984) in "Bergey's Manual of Determinative Bacteriology". The identification of bacteria was done with the help of Computer program, PIBWin (www.soton.ac.in.uk/tnb/pib.htm).

Preparation of earthworm paste: Earthworms (Perionyx excavatus, Pheretima posthuma) were obtained from Vermicomposting unit of the department of Zoology. Sexually mature clitellated worms were washed with running tap water and then fed with wet blotting paper for 18-20 hours for gut clearance. The gut cleared worms were again washed with distilled water. The worms were kept in plastic trough covered tightly with polythene cover and exposed to sunlight for three days to kill the earthworms. Mucus and coelomic fluid that will ooze out formed a brown coloured paste called earthworm paste. After mastication of whole earthworm obtained with mucus and coelomic fluid, a brown coloured paste was formed. (Balamurugan et al., 2007)

Well diffusion technique: Nutrient agar (NA) was cooled at $45^{\circ} \mathrm{C}$ and inoculated with the target organism to a final density of $10^{7}$ cells $/ \mathrm{ml}$ agar media and was poured into the Petri dishes as described by Gram and Melchiorsen, (1996). The plates were kept in Laminar Air Flow for $30 \mathrm{~min}$. to allow solidification. With the help of cork-borer, three wells were prepared in each solidified agar plate and were sealed with water agar. The earthworm extract $(50 \mathrm{ml})$ was inoculated in wells $(\mathrm{r}=0.25 \mathrm{~cm})$ with the help of a micropipette. The plates were then incubated at $32 \pm 1^{0} \mathrm{C}$ in B.O.D. incubator and observations were recorded for zone of inhibition around the wells after $24 \mathrm{~h}$. The clear zone of inhibition was measured using a centimeter scale and the observations were recorded.

Statistical analysis: The obtained results were analyzed statistically using completely randomized design (CRD) following Snedecor and Cochran (1989). Statistical analysis was performed using analyses of variance (One-way ANOVA) and Student's ttest to determine differences between treatments (levels of significance are expressed as $\mathrm{P}<0.05$ ).

\section{RESULTS}

The present investigation was made to identify the antibacterial activity of earthworm extract and see their potential in controlling fish bacterial diseases. Isolation of bacterial strains was done form healthy and diseased C. carpio collected from fish farms/ ponds in Hisar. 
Table 1. Incubation period of different pathogenic bacteria for the appearance of disease symptoms in Cyprinus carpio (Mean values are of three replicates).

\begin{tabular}{|c|c|}
\hline Pathogenic bacteria & $\begin{array}{c}\text { Incubation period (in days) }{ }^{\mathrm{a}} \text { of bacteria for } \\
\text { the appearance of disease symptoms }\end{array}$ \\
\hline \multicolumn{2}{|c|}{ Gram negative } \\
\hline A. hydrophila & $3.34 \pm 0.33$ \\
\hline E. coli & $7.64 \pm 0.57$ \\
\hline E. aerogens & $8.32 \pm 0.33$ \\
\hline Shigella spp. & $8.47 \pm 0.33$ \\
\hline P. fluorescens & $6.75 \pm 0.68$ \\
\hline P. aeruginosa & $8.13 \pm 0.33$ \\
\hline \multicolumn{2}{|c|}{ Gram positive } \\
\hline M. luteus & $7.00 \pm 0.33$ \\
\hline S. aureus & $5.07 \pm 0.57$ \\
\hline CD Value $(\mathrm{P} \leq 0.05)$ & 0.24 \\
\hline \multicolumn{2}{|c|}{$\mathrm{a}=$ Mean \pm S.E. $; C D=$ Critical difference at $5 \%$ level of significance } \\
\hline \multirow[t]{2}{*}{ Pathogenic bacteria } & Longevity (in days) ${ }^{a}$ \\
\hline & Gram negative \\
\hline A. hydrophila & $8.66 \pm 0.33$ \\
\hline E. coli & $12.14 \pm 0.57$ \\
\hline E. aerogens & $15.52 \pm 0.33$ \\
\hline Shigella spp. & $16.37 \pm 0.33$ \\
\hline P. fluorescens & $11.53 \pm 1.20$ \\
\hline P. aeruginosa & $13.70 \pm 0.57$ \\
\hline \multicolumn{2}{|c|}{ Gram positive } \\
\hline M. luteus & $13.25 \pm 0.33$ \\
\hline S. aureus & $10.38 \pm 0.57$ \\
\hline $\mathrm{CD}(\mathrm{P} \leq 0.05)$ & 0.28 \\
\hline
\end{tabular}

$\mathrm{a}=$ Mean \pm S.E. $; C D=$ Critical difference at $5 \%$ level of significance

Table 3. Antibacterial activity (in $\mathrm{mm}$ ) of Perionyx excavatus and Pheretima posthuma against pathogenic bacteria ((Mean values are of three replicates).

\begin{tabular}{lcccccc}
\hline $\begin{array}{l}\text { Bacterial } \\
\text { strains }\end{array}$ & \multicolumn{3}{c}{ Perionyx excavates } & \multicolumn{3}{c}{ Pheretima posthuma } \\
\cline { 2 - 7 } & $\begin{array}{c}\text { Pure Ex- } \\
\text { tract }\end{array}$ & $\begin{array}{c}\text { Extract:Ethanol } \\
\mathbf{1 : 1}\end{array}$ & $\begin{array}{c}\text { Extract: Etha- } \\
\text { nol } \\
\mathbf{1 : 2}\end{array}$ & $\begin{array}{c}\text { Pure } \\
\text { Extract }\end{array}$ & $\begin{array}{c}\text { Extract: Etha- } \\
\text { nol 1:1 }\end{array}$ & $\begin{array}{c}\text { Extract: } \\
\text { Ethanol 1:2 }\end{array}$ \\
\hline A. hydrophila & $15.33 \pm 0.33$ & $18.33 \pm 0.66$ & $15.33 \pm 0.66$ & $15.00 \pm 0.57$ & $16.66 \pm 0.33$ & $13.00 \pm 0.57$ \\
S. aureus & $17.00 \pm 0.57$ & $17.66 \pm 0.66$ & $14.33 \pm 0.33$ & $11.66 \pm 0.33$ & $14.00 \pm 0.57$ & $10.00 \pm 0.37$ \\
P. aeruginosa & $14.66 \pm 0.33$ & $15.33 \pm 0.33$ & $12.33 \pm 0.66$ & - & - & - \\
P. fluorescens & $15.00 \pm 0.57$ & $18.00 \pm 0.57$ & $14.33 \pm 0.33$ & $12.66 \pm 0.33$ & $14.33 \pm 0.33$ & $8.66 \pm 0.66$ \\
M. luteus & $11.33 \pm 0.88$ & $12.66 \pm 0.66$ & $9.66 \pm 0.33$ & - & - & - \\
E. coli & $17.00 \pm 0.57$ & $17.33 \pm 0.33$ & $15.33 \pm 0.33$ & $13.33 \pm 0.33$ & $14.33 \pm 0.66$ & $10.66 \pm 0.33$ \\
E. aerogens & $14.66 \pm 0.33$ & $16.33 \pm 0.33$ & $13.66 \pm 0.66$ & - & - & - \\
Shigella spp. & - & - & - & - & - & - \\
C.D. (P $\leq 0.05)$ & 1.55 & 1.51 & 1.42 & 0.87 & 1.06 & 1.00 \\
\hline CD-Cit & & & & &
\end{tabular}

$\mathrm{CD}=$ Critical difference at $5 \%$ level of significance 
The diseased fish showed symptoms like hemorrhages on head and lateral side of the body, skin erosions, fin $\&$ tail erosion, ulcers and rottening of gill lamella. Isolated pure cultures of bacteria were subjected to a number of important biochemical tests. Eight bacterial strains were isolated and identified from $C$. carpio (Table 1).

Longevity of $C$. carpio inoculated with different pathogenic bacteria: The fish injected with Aeromonas hydrophila survived for about 8 days of post inoculation (Table-2). The A. hydrophila was the most pathogenic bacterium among the isolated strains. Pseudomonas fluorescens and Staphylococcus aureus was also quite pathogenic as fish could live just for about 10-11 days post inoculation and mortality observed was $80.25 \%$ (Table 2). Among pathogenic bacteria maximum longevity was seen in Shigella spp. wherein fish survived for about 16 days. This was followed by fish injected with Enterobacter aerogens where longevity observed was about 15 days.

Antibacterial activity shown by earthworm species against isolated pathogenic bacteria: Total eight bacterial strains isolated from infected fish. The earthworm species i.e. P. excavatus, $P$. posthuma, were tested for their antagonistic behavior towards pathogenic bacterial strains using well diffusion technique. The results of the in vitro antagonism tests were presented in Table 3. The maximum values of zone of inhibition against the fish bacterial pathogens were given by $P$. excavatus, $P$. posthuma in the composition of 1:1 (Extract: Ethanol).

The mean values of the zone of inhibition observed for Perionyx excavatus against the Gram-ve bacteria were; $18.00 \mathrm{~mm}$ (P. fluorescens), $18.33 \mathrm{~mm}$ (A. hydrophila), $15.33 \mathrm{~mm}$ ( $P$. aeruginosa), $16.33 \mathrm{~mm}$ (E. aerogenes), $17.33 \mathrm{~mm}$ (E.coli) and against Gram+ve bacteria were $17.66 \mathrm{~mm}$ (S. aureus), $12.66 \mathrm{~mm}$ ( M. luteus) as shown in Table-3 .

The maximum zone of inhibition observed for $P$. excavatus was $18.33 \mathrm{~mm}$ against $A$. hydrophila and the minimum was $15.33 \mathrm{~mm}$ against $P$. aeruginosa in Gram-ve bacteria whereas no zone of inhibition was observed against Shigella spp. In case of Gram+ve bacteria the maximum value observed was $17.66 \mathrm{~mm}$ against $S$. aureus.

The mean values of the zone of inhibition observed for $P$. posthuma against the Gram-ve bacteria were; 14.33 mm (P. fluorescens), $16.66 \mathrm{~mm}$ (A. hydrophila), 14.33 $\mathrm{mm}$ (E.coli) and against Gram+ve bacteria were 14.00 $\mathrm{mm}(S$. aureus), as shown in Table 3.

The maximum zone of inhibition observed for $P$. posthuma was $16.66 \mathrm{~mm}$ against $A$. hydrophila and the minimum were against $P$. fluorescens and E.coli whereas no zone of inhibiyion shown against $P$. aeruginosa, E. aerogenes and Shigell sp. in Gram -ve bacteria. In case of Gram+ve bacteria the maximum value observed was $21.33 \mathrm{~mm}$ against $S$. aureus and no antibacterial activity shown against $M$. luteus.

\section{DISCUSSION}

Fish Diseases are major problem for the fish farming industry, which currently is the fastest growing food-protein producing sector with an annual increase of approximately $9 \%$, among those, bacterial infections are considered as the major cause of mortality in fish hatcheries (Kirjusina et al., 2007). The motile aeromonads, especially $A$. hydrophila, affects a wide variety of freshwater fish species and occasionally marine fish (Chu and $\mathrm{Lu}, 2005$ ). The prophylactic and therapeutic control of the bacterial diseases is based on oral administration of antibiotics. However, such treatment may cause the development of resistant bacteria (Aoki et al., 1985), yield residues in fish and introduce potential hazard to public health and to the environment. A new approach method, that is gaining acceptance within the industry, is the use of earthworm extract to control potential pathogens. The present investigations were therefore taken and have been presented and discussed in detail.

The present study was successfully done with collection and culture of earthworm, $P$. excavatus and P. posthuma and were subjected to tested against various isolated bacterial strains from diseased common carp.

In vitro antagonism test: In the present study in vitro Antagonism test following well diffusion assay was conducted to determine the zone of inhibition of earthworm extract against various fish pathogens. The maximum values of zone of inhibition against the fish bacterial pathogens were given by earthworm extract: ethanol (1:1) followed by pure extract and earthworm extract : ethanol (1:2) among all the composition used. The results of the study can be associated to study of Vasanthi et al. (2013) worked on antimicrobial activity of earthworm paste Eudrilus eugeniae and found that earthworm paste at a dose of $100 \mu 1$ was able to inhibit the growth of bacteria of $S$. aureus at a maximum level compared to other bacteria; the growth of fungal Candida albicans was much inhibited. The minimum inhibitory concentration (MIC) indicated that earthworm paste at a dose of $200 \mu$ l inhibited the bacterial growth and clearly indicated that the paste contain a good antibacterial potential and the bioactive compounds to inhibit the growth of bacteria and fungi. Hence earthworm paste (EP) has a good potential to develop a new drug.

Similar results were observed by Mathur et al. (2010) on antimicrobial activity of earthworm extracts of various solvents and found that found that $95 \%$ ethanol extract of earthworm was potent antibacterial agent against Streptococcus pyogens and antifungal agent against $C$. albicans. Petroleum ether extract showed maximum potency against $S$. aureus in comparison to S. pyogens. Petroleum ether extract was found to possess maximum antifungal activity against $A$. niger in comparison to $C$. albicans. Against $E$. coli, ethanol and petroleum ether extract possessed least antibacterial activity. Phosphate buffer extract of earthworm 
possessed no potency against bacterial and fungal cultures. These studies may lead to the formulation of new antimicrobial drug. Istiqumah et al. (2012) studied to determine the inhibitory of earthworm (Lumbricus rubellus) extract (ECT) and encapsulated earthworm extract (ECT-t) as poultry feed additive against some pathogenic bacteria and found that in vitro antibacterial activity was performed using dilution method against E. coli, S. aureus, Salmonella pullorum, and $P$. aeruginosa. Elif Ozlem and Cotuk (2008) worked on antibacterial and haemolytic activity of the coelomic fluid of Dendrobaena veneta (Oligochaeta, Lumbricidae) living in different localities and concluded that coelomic fluid of Beykoz earthworms was a potential agent, which can be used as an alternative drug, since this coelomic fluid was effective against bacteria. The results of present study showed that maximum antibacterial activity was against gram negative bacteria. Similar findings have been reported by Verma and Verma (2012) who found that coelomic fluid of earthworm $P$. posthumous had maximum antibacterial activity against E.coli $(19.00 \mathrm{~mm})$. The present findings are in agreement of the results of Anitha and Jayraaj (2013) who reported that the earthworm powder obtained from Eudrilus eugeniae had strong antibacterial and antifungal activity. The similarity of this study was also evidenced by Chauhan et. al. (2014), who observed that extract of E.eugeniae had maximum antibacterial activity with gram negative $P$. aeruginosa. Bhorgin and Uma (2014) showed that ethanolic extract of earthworm powder possessed maximum antibacterial activity in comparison with petroleum ether and aqueous extract against $A$. hydrophila.

\section{Conclusion}

From the present study it was concluded that, the earthworm extract can be effectively used as a potential antimicrobial agents to overcome the problem of bacterial infection, so as to enable to enhance the market revenue throughout the world. It can also be stated that earthworm extract can reduce the incidence and duration of diseases. The application of earthworm extract in aquaculture showed promise but needs considerable efforts of research.

\section{ACKNOWLEDGEMENTS}

We thank the authorities of CCSHAU, Hisar for facilities and Professor and Head, Department of Zoology, College of Basic Sciences \& Humanities, CCSHAU, Hisar for help in the conductance of the study. The authors are thankful to Department of Science \& Technology, Govt. of India for their financial support to carry out the research.

\section{REFERENCES}

Akinbowale, O.L., Peng, H. and Barton, M.D. (2006). Antimicrobial resistance in bacteria isolated from aquaculture sources in Australia. J. App. Microbiol.
100: 1103-1113.

Anitha, J. and Jayraaj, Indira A. (2013). In-vitro antibacterial activity and evaluation of flavonoid and phenol in earthworm powder (Eudrilus eugeniae). World journal of pharmacy and pharmaceutical sciences. 2(6): 4917 $-4928$.

Ansari, A.A. and Sitaram, K. (2010). An investigation on the anti-microbial and anti-fungal properties of earthworm powder obtained from Eisenia foetida. Int. J. Microbio. res. 1(2): 62-66.

Aoki, T.; Kanazawa, T. and Kitao, T. (1985): Epidemiological surveillance of drug-resistant Vibrio anguillarum strains. Fish Patho., 20: 199-208.

Bachere, E., Mialhe, E., Noël, D., Boul, V., Morvan, A. and Rodrigues, J. (1995). Knowledge and research prospects in marine mollusc and crustacean immunology. Aquacult. 132: 17-32.

Bader, J.A., Shoemaker, C.A. and Klesius, P.H. (2003). Rapid detection of columnaris disease in channel catfish (ktalurus punctatus) with a new species specific 16S rRNA gene based PCR primer for Flavobacterium columnare. J Microbiol. Met. 52 (2): 209-219.

Balamurugan, M., Parthasarathi, K., Cooper E.L. and Ranganathan, L.S. (2007). Earthworm paste (Lampito mauritii, Kinberg) alters inflammatory, oxidative, haematological and serum biochemical indices of inflamed rat, European Review for Medical and Pharmacological Sciences. 11 : 77-90.

Balamurugan, M., Parthasarathi, K., Cooper E.L. and Rangnathan, L.S. (2009). Anti-inflammatory and anti-pyretic activities of earthworm extract- Lampito mauritti (Kinberg). J. Ethnopharm. 121(2): 330-332.

Bhorgin, A.J. and Uma, K. (2014). Antimicrobial activity of Earthworm Powder (Lampito mauritii). Int. J. Curr. Microbiol. App. Sci. 3(1): 437-443

Chauhan, P.S., Tomar Jyoti, Prasad, G.B.K.S. and Agrawal, O.P. (2014). Evaluation of antimicrobial activity if earthworm tissue extract of Eudrilus eugeniae. Jour. Chem. And Pharmaceu. Res. 6(8); 28-38

Chu, W.H. and Lu, C.P. (2005). Multiplex PCR assay for the detection of pathogenic Aeromonas hydrophila. Journal of Fish Diseases. 28(7): 437-441

Cooper, E.L. (2005). CAM, eCAM, bioprospecting: the 21st century pyramid, Evidence Based Complementary Ancient Medicines $2: 125-127$.

Cooper, E.L. and Balamurugan, M. (2010). Unearthing a source of medicinal molecules. J. Ethnopharm. 10: 70-76.

Edwards C.A. and Bohlen, P.J. (1996). Biology and Ecology of Earthworms (third edition), Chapman and Hall, London.

Elif Ozlem Arslan-Aydoğdu and Çotuk Ayşın. (2008). Antibacterial and Hemolytic Activity of the Coelomic Fluid of Dendrobaena veneta (Oligochaeta, Lumbricidae) Living in Different Localities. IUFS J Biol 2008, 67 (1):23-32

El-Kamali, H.H. (2000). Folk medicinal use of some animal products in Central Sudan. J. Ethnopharm. 72: 279-289.

FAO (2009). State of world fisheries and aquaculture. Fisheries aquaculture department- ISBN978-92-5 -106029-2

Gomez R, Balcázar J.L. and Shen M.A. (2007). Probiotics as Control Agents in Aquaculture. J. Ocean Uni. China, 6 (1): 76-79.

Gram, L. and Melchiorsen, J. (1996). Interaction between fish spoilage bacteria Pseudomonas sp. and Shewanella putrefaciens in fish extracts and on fish tissue. J. Appl. 
Bacteriol. 80: 589-595.

Hrzenjak, T., Popovic, M., Bozic, T., Grdisa, M., Kobrehel, D. and Rudman, L. (1998). Fibrinolytic and anticoagulative activities from the earthworm Eisenia foetida. Comp. Biochem. and Physiol. 119: 825-832. http://nfdb.gov.in/html/aboutus.htm

Ismail, S.A. (2005). The Earthworm Book. Other India Press, Apusa, Goa, pp: 101

Istiqomah, L., Herdian, H., Damayanti, E., Hayati, S.N. and Julendra, H. (2012). Inhibitory of Encapsulated Earthworm Extract (Lumbricus rubellus) on Pathogenic Bacteria in Vitro. Media Peternakan, April 2012, pp. 1-8.

John, S.A. and Packialakshmi, N. (2007). Studies on antimicrobial activity of Perionyx excavatus. Pakistan journal of biological sciences. 10(19): 3482-3484.

Joseph, A. and Clerk G.C. (2002). Infestation of fish-culturing communities with fish-borne bacteria: The Ghanain case. Int. J. Environ. Health Res. 12(3): 277-282.

Kirjusina M., Briede I. and Bondad-Reantaso M.G. (2007) Extension Manual on Some Important Viruses, Parasites and Bacteria of Aquatic Animals in Latvia. NDC/LZRA/FAO. Riga. $69 \mathrm{p}$

Krieg, N. R. and Holt, J. G. (1984). Identification of bacteria In: Bergey's manual of systematic bacteriology. Vol.I Williams \& Wilkins Baltimore, London. pp. 24-26.

Mathur, A., Satish K. Verma, Rakshanda Bhat, Santosh K. Singh, Archana Prakash, G.B.K.S. Prasad and Dua, V. K.. (2010). Antimicrobial Activity of Earthworm Extracts. Int jou of Pharma Scie. 2(4): 364-370.

Popovi, M., Mihaela, T.H.R., Babi, T., Kos J. and Grdisa, M.A. (2001). Effect of earthworm (G-90) extract on formation and lysis of clots originated from venous blood of dogs with cardiopathies and with malignant tumors, Pathology Oncology Research 7 :197-202.

Prakash, M., Balamurugan, M., Parthasarathi, K., Gunasekaran, G., Cooper E.L. and Ranganathan, L.S. (2007).
Anti-ulceral and anti-oxidative properties of "earthworm paste" of Lampito mauritii (Kinberg) on Rattus norvegicus, European Review for Medical and Pharmacological Sciences 11 : 9-15.

Ranganathan, L.S. (2006). Vermibiotechnology-From SoilHealth to Human Health. Agrobios, Jodhpur, India.

Schwarz, S., Kehrenberg, C. and Walsh, T.R. (2001). Use of antimicrobial agents in veterinary medicine and food animal production. Intern. J. Antimicrob. Agent. 17: 431 $-437$.

Shobha, S.V. and Kale, R. (2007). Antimicrobial potency of Eudrillus eugeinae on certain plant pathogen//abstract $8^{\text {th }}$ Int. Symp.on earthworm ecology, Kracow, Poland, 4 -9 sept, 2006, pp-245.

Snedecor, G. and Cochran, W. (1989). Statistical Methods (8th edition). The Iowa State University Press.

Vasanthi, K., Chairman, K. and Ranjit Singh, A.J.A. 2013. Antimicrobial activity of earthworm paste Eudrilus eugeniae. African journal of Environmental Science and Technology. 7(8): 789-793

Verma, V.K. And Verma, M.K. 2012. Earthworm- a potential source for stable and potent antimicrobial compounds - isolation and purification study. Int $j$ pharm pharm sci. 4(4) : 540-543

Verschuere, L., Rombaut, G., Sorgeloos, P. and Verstraete, W. (2000). Probiotic bacteria as biological control agents in aquaculture. Microbiol. Molec. Biol. Rev. 64: 655-671

Wang, C., Sun, Z., Liu, Y., Zhang, X. and Xu, G. (2007). A novel antimicrobial vermipeptide family from earthworm Eisenia fetida. European journal of soil biology. 43: 127-134.

Yegnanarayan, R., Ismail S.A. and Shortri, D.S. (1988). Anti -inflammatory activity of two earthworm potions in Carrageenan pedal oedema test in rats, Indian Journal of Physiology and Pharmacology $32: 72-74$. 